\title{
The Impact of Religious Institutions on Economic Growth in Indonesia: Evidence from Selected Province
}

\author{
DOI 10.18196/AIIJIS.2020.0112.40-57
}

\section{LISTIONO ${ }^{1}$}

Sharia Economics, Faculty of Islamic Studies, Universitas Muhammadiyah Yogyakarta ${ }^{1}$ Correspondence Email: listio.tl@gmail.com

\begin{abstract}
In recent years, the study of the influence of religion on the economy is rising. However, in Indonesian context there is limited number of literature that specifically explores the relationship between religion and economic. To fill this gap, this article aims to investigate the effect of religion -with religious institutions as proxies- on economic growth using panel data from 2010 to 2017 of selected provinces. This model based on the Cobb-Douglas model and estimated using fixed-effects. The result shows that economic growth positive significantly affected by Protestant and Hindu variables. On other side, there in no strong evidence that Islam and Catholic have siginificant impact on economic growth. This paper does not claim that one religion is better than others in terms of economic activity, as measured by economic growth, but rather on how the role of religious institutions on social networks encourage economic growth. An important point of this paper is that in Indonesian context, religion has significant influences on the economic growth as in many other countries. Keywords: Religion, economic growth, Indonesia, fixed-effects.
\end{abstract}

\footnotetext{
ABSTRAK

Dalam beberapa tahun terakhir, studi tentang pengaruh agama terhadap ekonomi sangat populer. Namun, dalam konteks Indonesia belum ditemukan literatur yang secara khusus mengeksplorasi hubungan antara agama dan ekonomi. Untuk mengisi gap tersebut, artikel ini bertujuan untuk menganalisis pengaruh agama -dengan proksi institusi agama- terhadap pertumbuhan ekonomi menggunakan data panel dari tahun 2010 hingga 2017 dari beberapa provinsi terpilih. Model ini berdasarkan pada model Cobb-Douglas dan diestimasi menggunakan fixed-effects. Hasil penelitian menunjukkan bahwa pertumbuhan ekonomi secara positif dan signifikan dipengaruhi oleh variabel institusi agama Protestan dan Hindu. Di sisi lain, tidak ditemukan bukti yang kuat pengaruh institusi agama Islam dan Katolik terhadap
} 
pertumbuhan ekonomi. Paper ini tidak mengklaim bahwa satu agama lebih baik daripada yang lain dalam hal kegiatan ekonomi, yang diukur dengan pertumbuhan ekonomi, tetapi lebih pada bagaimana peran institusi agama dalam jaringan sosial dan mendorong pertumbuhan ekonomi. Poin penting dari tulisan ini adalah bahwa di Indonesia, agama juga memiliki pengaruh yang signifikan terhadap pertumbuhan ekonomi, sebagaimana negara-negara lain di dunia.

Kata kunci: Agama, pertumbuhan ekonomi, Indonesia, fixedeffects

\section{INTRODUCTION}

Economic growth as one of the objectives of macroeconomics always interesting to investigate, where capital, labor and technology are the basic factors of economic growth as the focus of discussion. In its development, the study of economic growth does not only focus on that factors, but also began to include other variables that were considered influential on economic growth, one of which was cultural variables as done by Franke, Hofstede, and Bond ', Abrams and Lewis², Adams ${ }^{3}$, Maridal', as well as Petrakis and Kostis. ${ }^{5}$ However, in the fact classical economists such as Adam Smith and Torstein Veblen had first seen that culture was one of the instrument forming economic outcomes, but at the end of the 19th century the study of culture was the domain of sociology, anthropology and organizational studies $^{6}$, so the study of the relationship between culture and economics became less popular.

In the study of relationship between cultural and economic have been carried out that mentioned before also includes religious variables, where religion is considered as the basic of the formation of a community culture. Qayum, Anjum, and Sabir argued that religion is the main factor outside economic that construct primary of institutional structure in the community 7. The study of the relationship between religion and the economy certainly cannot be separated from the idea of Weber (1930) in "The Protestant Ethics and the Spirit Capitalism", where one of them is the specific relationship between Protestant ethics and the emergence of the spirit of capitalism in the 16th and 17 th centuries in Europe. ${ }^{8}$ More specific studies of the relationship between religion and economics have been carried out by several scholars such as Blum and Dudley ${ }^{9}$ Barro and McCleary ${ }^{10}$, Noland ${ }^{11}$, McCleary and Barro ${ }^{12}$, Eum ${ }^{13}$, Wang and Lin ${ }^{14}$, also Sequeira, Viegas, and Ferreira-Lopes. ${ }^{15}$

McCleary and Barro stated in their study that the relationship between religion and economics at least can be seen from two sides.$^{16}$ First, religion as the dependent variable is to understand the influence of economic and politi- 
cal developments on religion. Second, religion as an independent variable is to tell the influence of religion in economic and political development. Religion as the dependent variable tends to be seen how economic activity and political policy influence religious activities. Meanwhile, religion as an independent variable is more seen in how religion influences individual behavior which ultimately impacts on political-economic decisions and activities.

Meanwhile, according to Palanca the influence of religion on economic development is at least through two channels, namely motivation and institutional factors. ${ }^{17}$ According to him, non-economic factors such as politics, culture, religion and ideology should be present and provide motivation and form the right institutional order. The presence of enthusiasm motivated by religious teachings will certainly encourage economic behavior to be more ethical in working (entrepreneurship). In addition, well-understood religious teachings can also motivate someone to be more productive, and increase philanthropic activities, which in turn can encourage equitable income (development). On the other hand, the influence of religion through institutional factors such as the provision of education, health services, and social activities such as charity and empowerment.

Indonesia with a diversity of ethnicities, religions and cultures certainly has more or less influenced economic growth. However, the author has not found a study of the relationship between religion and economic growth in Indonesia. In the international literature the study of economic growth in Indonesia examines more how economic growth is influenced by other factors outside of religion such as technological developments ${ }^{18}$, populations ${ }^{19}$ ${ }^{20}$, and open trade, real exchange rates and domestic investment. ${ }^{21}$

In relation to religious conditions, Indonesia has different characteristics compared to other ASEAN countries, such as Malaysia and Thailand. Based on data from the 2005-2009 World Value Survey (WVS), 94 percent of Indonesians consider religion to be very important, while Malaysia and Thailand only account for 80.45 percent and 56 percent respectively. Next, 75.3 percent of Indonesians consider themselves religious, while Malaysia and Thailand account for 88.8 percent and 35.5 percent. Finally, 85.2 percent of Indonesia's population stated that in daily life God is very important, for Malaysia and Thailand each only 40.3 percent and 18.1 percent. From the data above, it can be seen that religion and God are two things that cannot be separated from the lives of both individuals and society in Indonesia context. 
Table 1.1. The Importance of Religion (\%)

\begin{tabular}{lllll}
\hline Answer & TOTAL & Countries & & \\
& & Indonesia & Malaysia & Thailand \\
\hline Very important & $78,3 \%$ & $94 \%$ & $80,4 \%$ & $56 \%$ \\
Not too important & $17,8 \%$ & $4 \%$ & $15,5 \%$ & $37,7 \%$ \\
Very unimportant & $2,9 \%$ & $0,9 \%$ & $3,3 \%$ & $5,3 \%$ \\
Absolutely not important & $0,4 \%$ & $0,3 \%$ & $0,7 \%$ & $0,4 \%$ \\
No answer & $0,5 \%$ & $0,6 \%$ & $0,1 \%$ & $0,5 \%$ \\
Tidak tahu & $0,1 \%$ & $0,1 \%$ & $0 \%$ & $0 \%$ \\
\hline (N) & $(4.750)$ & $(2.015)$ & $(1.201)$ & $(1.534)$ \\
\hline
\end{tabular}

Source: World Values Survey Wave 5: 2005-2009

Based on the description above, the researcher is interested in examining religious relations and economic growth in Indonesia. Considering that Indonesia has a diversity of religions, where the behavior of the Indonesian people is much influenced by the teachings of the religion followed and there are many public institutions (education, health and social activities) provided by religious institutions. Indonesia, besides being the country with the largest population in the world, is also known as a country with a diversity of tribes, races and religions. In addition, the Indonesian population is also said to be a religious population. This means that in addition to adhering to and believing in a particular religion, the community also adheres to the teachings of religion well, therefore it will be interesting to know whether religious variables influence the growth of the Indonesian economy.

\section{LITERATURE REVIEW}

According to Palanca the relationship between religion and growth (economy) is a reciprocal relationship. ${ }^{22}$ On one side of religion is a factor that stimulates economic activity and shows the transformation of changes in the structure of society and the economy. But on the other hand, religion changes as influenced by social and economic developments. According to him the influence of religion in development involves motivation and institutional factors, where both (motivation and institutions) are important factors in the development of a country. As Weber's thesis argues that in a motivational approach, economic growth is stimulated by economic ethics provided by religion, especially in Protestant ethics which encourages entrepreneurial activity and wealth gathering. Ethics encourages a person not only to work and raise money, but also how to save and invest his money in a pro- 
ductive place. Palanca further sees that this attitude towards business and work is what Weber calls rational, being careful, planning and considering everything in action. Meanwhile from the institutional approach, religion influences culture, behavior and changes in social and economic structures. Rationalism encourages new patterns in human relations, building new organizations and institutions in education, law, science, and technology. The impact of Protestant ethical reform not only affected the economy, but also on the legal system, political structure and all fields of knowledge.

McCleary and Barro argue that in religious and political economy studies, religion has two lines of interaction, namely religion as the dependent variable and religion as the independent variable. ${ }^{23}$ In the first path, economic development reduces individual participation in formal religious services and personal worship, reduces religious beliefs, and reduces the influence of religious organizations in politics and government. While the second pathway, religion as an independent variable is through the influence of religious beliefs in cultivating attitudes such as ethics in work, honesty, frugality, charity (wealth distribution), friendliness and so on. Salvation, punishment and heaven are great motivators for human behavior in this world. Trust in these three things can increase productivity by cultivating characteristics such as honesty, work ethics and frugality. According to Wang and Lin the mechanism of the influence of religion on economic growth is, first through religion influencing political preferences, the quality of government and economic policy. Second, religion influences education, health and the accumulation of human capital. Finally, Religion is useful in reducing transaction costs through work ethics. $^{24}$

Studies of the influence of religion on the economy have been carried out by many experts, including Barro and McCleary according to him religion as an important dimension of culture, where culture influences outcomes economically through its influence on individual traits such as honesty and work ethics. ${ }^{25}$ Barro and McCleary conducted a study using international religiosity survey data collected by the World Value Survey (1981-1984, 1990-1993, and 1995-1997), International Social Survey Program (1990-1998 and 19982000) and the Gallup Millennium Survey (1999). The sample used is as many as 59 countries using panel data. In this study the variables used to analyze the influence of religion on economic growth are variables of economic growth, attendance to places of worship (monthly), belief in hell and heaven, and the proportion of adherents of each religion (Eastern, Jewish, Islamic, Orthodox, 
Protestant, and other religions). The results of the study indicate that increasing attendance at places of worship tends to reduce economic growth. Conversely, increasing trust in hell and heaven tends to increase economic growth. While the proportion of Hindus, Muslims, Orthodox and Protestants has a significant negative effect on economic growth. In addition, Barro and McCleary also analyzed how the influence of economic variables (GDP per capita), demographics and religion had an effect on individual religiosity. The results showed that per capita GDP did not significantly influence religiosity.

Noland examined the relationship between religion and economic performance using cross-country data which was then estimated by ordinary least squares regression and two-stage least squares IV (instrumental variables) in a variety of models. ${ }^{26}$ The independent variable used is the growth of total factor productivity and growth in real income per capita. While for religious variables using data on affiliations of Catholic, Protestant, Orthodox, Muslim, Jewish, Hindu and Buddhist religions. In addition, several variables such as per capita Gross Domestic Product, investment, government spending, international trade and education are also included in the model. The estimation results with the first model of the study show that the proportion of Jews, Catholics and Protestants has a negative correlation with the growth of per capita income. For the estimation results with the second model the results show that the proportion of Buddhists as well as Christians is positive and significant towards the growth of per capita income. In addition, Noland also conducted cross-country analysis specifically for Arab and Muslim countries, this was motivated by the condition of Muslims who were relatively poor both individually and in the country. The results showed that the proportion of Muslim population had a significant positive effect on total factor productivity, interestingly the distance weighted Muslim inverse variable also had a significant positive effect on the total factor of productivity. Finally, Noland also conducted an analysis of countries with different ethnicities and different earth states, namely India, Malaysia and Ghana. According to him, crossnational analysis is not able to control the country's economy specifically, political and institutional influences. Estimated results in India show that Buddhist affiliation, Jain and other religions have a positive and significant effect on real income per capita. Meanwhile for Malaysia, Muslim, Christian, Hindu and Buddhist shares have a negative and significant effect. Christianity in Ghana has a negative and significant effect on regional per capita income, in contrast Islam is positive and significant. According to Noland, the results of 
this study break the notion that Islam is a religion that impedes economic growth.

McCleary and Barro developed a previous study (2003) by analyzing religion from two sides, namely religion as an independent variable and religion as the dependent variable.27 In the first analysis, McCleary and Barro estimated how individual religiosity was influenced by economic variables (GDP per capita) and religion (state religion, regulations on religion, pluralism, communism and fractions of religions) using instrumental variables in 81 countries. The results in variety models showed that, Gross Domestic Product per capita had a significant and negative effect on individual religiosity. The results of this study are also different from previous studies, where GDP percapita did not significantly influence of religiosity. While in the second analysis, only trust in hell has a significant positive effect on economic growth, while other variables such as attendance to places of worship, Muslims and Protestant shares have a negative and significant effect on economic growth.

Wang and Lin analyzed the impact of religious beliefs on economic growth using provincial panel data in China over 2001 until 2011. ${ }^{28}$ Wang and Lin's research differs from several previous studies, namely by developing the CobbDouglas theory and including the number of religious institutions as religious proxies. According to him, the number of religious institutions shows the breadth and depth of the influence of religion on social life. The estimation model used Hausman and Tailor Generalized Least Squares (GLS), Amemiya and McCury (AM) and Fixed Effects Vector Decomposition (FEVD). The results showed that Islamic and Buddhist institutions had a negative and significant effect on economic growth, and only Christian institutions had a significant effect on economic growth.

Sequeira et al examined the relationship between religion and income, using panel data from 1925-1990 for 30 countries. ${ }^{29}$ The religious variable used is the presence of children and adult places of worship, then estimated by Error Correction Model (ECM) in a variety of models. The results of the study indicate that the presence of places of worship both by children and adults on the whole model does not significantly influence Gross Domestic Product per-capita. In other word, this finding confirm that participation on religius activities (measured by church attendance) have no impact on economic growth.

Several previous studies analyzed the relationship betwee religion and macro variables. Research related to the influence of religion on micro vari- 
ables or individual has also been carried out, including Kirchmaier, Prufer, and Trautmann ${ }^{30}$ as well as Lu and Wu $\mathrm{Wu}^{31}$. Kirchmaier, Prufer, and Trautmann investigated relationship between religion and economic behavior in Dutch setting. ${ }^{32}$ Variable religion include religious status, church attendace, private prayer, belief in God, and belief in theological concepts. They found that religious people more holding stringent ethical attitudes, more spending time on voluntary activities and informal care, and lower preference on distribution. Interestingly, they found religious people were less accepting immoral economic activities, such as bribery and tax evasion. The Protestants have less preference on redistribution, but employ more time in voluntary activities, while Catholics are more philanthropist.

Lu and Wu studied effect of religiosity on private firms performance including corporate governance in China. ${ }^{33}$ The variable of religion is dummy one if the entrepreneur or follows religion, while Return on Asset (ROA) and Return on Equity (ROE) are performance firms indicator. Shareholding reform, external CEO, family ownership, inheritance, and safety insurance are corporate governance indicators. In this research also include variables control, such as individual and firm characteristic. They argued that entrepreneur behavior is effected by religion principle. Lu and Wu found that firm with religious enterpreneurs more better performance, and better on credit acces. Religious enterprenuer in China also spend more on insurance as a form atlruism and risk aversion for employees, more trust to others, employ external CEO, and shareholding reform. Nevertheless fims with religious entrepreneur are more greater share of family members on firm ownership, and firms tend to inheritance by family members.

Previous studies have analyzed the influence of religion on the economy, emphasizing personal aspects such as believing in heaven and hell, attendance to places of worship, and so on. This research tries to explore from a different side, namely the role of religious institutions on the economy. If personal aspects influence the economy through motivation and attitudes, religious institutions play a greater role through social networks in the community. Karacuka argued that religious institutions are very important in social structures, that is by construction networks, consequently as to foster trust, cooperation, and reciprocity ${ }^{34}$. In other words, religious institutions are one source of social capital in society. The positive impacts of social capital include growing norms of reciprocal relations, facilitating communication and information distribution within the community. ${ }^{35}$ In addition, the influ- 
ence of religious institutions on the economy is related to economic development programs. ${ }^{36}$ In Indonesia, a lots of religious institutions such as mosques, churches, temples, and monasteries are involved in economic development, especially in surrounding communities.

\section{RESEARCH METHOD}

This paper used panel data over the period 2010-2017 for nine provinces, there are Sumatera Utara, Sumatera Barat, Bangka Belitung, Kepulauan Riau, DI Yogyakarta, Bali, Nusa Tenggara Timur (NT), Kalimantan Barat, and Sulawesi Utara. We used that provinces based on share of religion believers in population in each region (based on population census 2010 by BPS-Statistics Indonesian). The first, both of DI Yogyakarta and Sumatera Barat dominate by Islam. Second, Sumatera Utara and Sulawesi Utara dominate by Protestan. Third, Nusa Tenggara Timur and Kalimantan Barat dominate by Catholic. Fourth, Bali dominate by Hindu. Fifth, Kepulauan Riau and Bangka Belitung share of Buddhist and Konghucu more than other regions. The data collected from BPS-Statistic Indonesia.

This paper attempt to analyze the impact of religious-with religious institutions as proxies- on Indonesia economic growth. The model in this paper duplicated from Wang and Lin. ${ }^{37}$ The basic model in this paper based on Cobb-Douglas model and then placed in religious institution such as Mosque, Church, Temple, and Monastery as religion variable. Besides limited of data, especially personal aspects such as previous studies, the use of religious institutions is to investigate the influence of religion on the economy through social networks. The empirical model as follows:

$\ln \left(Y_{i t}\right)=\alpha+\beta_{1} \ln K_{i t}+\beta_{2} \ln L_{i t}+\beta_{3} \ln E_{i t}+\beta_{4} \ln R_{i t}+\mu_{i}+\varepsilon_{i t}$

Where $\mathrm{Y}$ is output (Gross Regional Domestic Products), $\mathrm{K}$ is capital consists of foreign direct investment (FDI) and domestic direct investment (DDI). Since, the data units of foreign direct investment (FDI) and domestic direct investment (DDI) are different, one of them on Rupiah and each other on $U \$$ dollar, so they are separated. $L$ is working population, $R$ is religious institutions that are Mosque (Muslim), Church (Protestan and Catholic), Temple (Hindu), and Monastery (Buddhist). The religious instititions that are houses of worhip potentially increases networks and interactions among believers then become element of social capital and positive impact on economic 
growth. ${ }^{38}$ The Confucius data excluded from the model because incomplete data for all provinces. In this model also used average scholl duration (E) as capital knowledge indicator.

\section{Tabel 1. Statistical description of variables}

\begin{tabular}{llrrrr} 
Variabels & \multicolumn{1}{c}{ Description } & \multicolumn{1}{c}{ Mean } & \multicolumn{1}{c}{ Std. } & \multicolumn{1}{c}{ Min } & \multicolumn{1}{c}{ Max } \\
\hline Y & Gross regional Domestic Products & $30,250.64$ & $17,013.63$ & $9,316.79$ & $80,330.54$ \\
$\mathrm{~L}$ & Number of worker & $2,126,713.00$ & $1,511,813.00$ & $555,258.00$ & $6,365,989.00$ \\
FDI & Foreign Direct Investment & 324.38 & 353.90 & 2.40 & $1,514.90$ \\
DDI & Domestic Direct Investment & $1,667.39$ & 2465.48 & 0.10 & $12,380.90$ \\
Educ & Average School Duration & 8.17 & 0.98 & 6.27 & 9.79 \\
Islam & The number of Mosque & $5,510.89$ & 6520.08 & 614.00 & $20,872.00$ \\
Protestan & The number of Protenstan Cruch & $2,890.09$ & 3677.22 & 150.00 & $12,401.00$ \\
Catholic & The number of Catholic Church & 911.85 & 1122.63 & 29.00 & $3,356.00$ \\
Hindu & The number of Temple & 568.79 & 1509.88 & 1.00 & $4,897.00$ \\
Buddhist & The number of Monastery & 88.14 & 126.58 & 2.00 & 393.00 \\
\hline
\end{tabular}

Sources: author's calculation

\section{DISCUSSION}

This paper used fixed-effects to identify the impact of religion -with religious institutions as proxies- on economic growth. According to Wooldridge for units of observation is a large (provinces or states level) and assumes that each á as a separate intercept to each cross-sectional unit, we can use fixed effects. ${ }^{39}$ Besides that, to ensure that the model using is appropriate we did Hausman test for formaly statistic test. The result of Hausman test shows that the null hypothesis is rejected, therefore fixed effects is properly. To ensure that model is robust, we construct two models, first model without basic variabels (labor, capital, and education) and model with labor, capital, and ducatio as control variables. The results are showed in table 2 , in the second model both of labor (number of worker) and education (average school duration) have positive impact and significant on economic growth. Therefore, provinces with a large of labor and higher on average of education have higher economic growth. Surprisingly, there is no strong evidence that both of capital variables namely Foreign Direct Investment (FDI) and Domestic Direct Investment (DDI) have significant impact on economic growth. Nevertheles this paper focuses on religion variables.

The main findings in this paper namely, first the Islam institutions as Islam proxy does not influence economic growth significantly. These result are consistent with Pryor ${ }^{40}$ who conducted research in countries with a majority of Muslim population indicating that the presence of Islam in a Muslim country 
is relatively a little influence on economic. However the result on full of variables (with basic variables) estimate show that Islam institutions has a negative sign on economic growth, although no significant effect. This finding consistent with Noland ${ }^{41}$, Barro and McCleary ${ }^{42}$, as well as Eum ${ }^{43}$. Noland found that Islam in cross-country analysis, even in Malaysia and India have negative impact on growth althought not significant. ${ }^{44}$ Nevertheless, the result was difference with Wang and Lin ${ }^{45}$ they found that Islam institutions in China significantly have negative impact on economic growth. Kuran also found that Muslim share has negative impact and significant on income per capita. ${ }^{46}$ In international level, in the most countries with Muslims majority tend poores than non-muslims countries. Pryor in his article argued that the content or substance of Islam doctrine often ignored, such as on prohibition of interest. ${ }^{47}$

Table 2. Estimation results

\begin{tabular}{lcc} 
& \multicolumn{2}{c}{ Fixed-Effects } \\
\cline { 2 - 3 } & Without basic variables & With basic variables \\
\hline $\mathrm{L}$ & & $0.5722^{* * *}$ \\
FDI & & $(0.165)$ \\
& & 0.0087 \\
$\mathrm{DDI}$ & & $(0.008)$ \\
& & -0.0013 \\
Educ & & $(0.004)$ \\
& & $1.8502^{* * *}$ \\
Islam & & $(0.309)$ \\
& & -0.0332 \\
Protestan & 0.1378 & $(0.054)$ \\
& $(0.109)$ & $0.0738^{* *}$ \\
Catholic & $0.2347^{* * *}$ & $(0.035)$ \\
& $(0.068)$ & -0.0425 \\
Hindu & -0.0506 & $(0.028)$ \\
& $(0.061)$ & $0.0418^{* *}$ \\
Buddhist & $0.0980^{* *}$ & $(0.018)$ \\
& $(0.038)$ & 0.0157 \\
Constant & $0.1185^{* *}$ & $(0.024)$ \\
& $(0.051)$ & -2.1386 \\
Observations & $6.9972^{* * *}$ & $(1.899)$ \\
R-squared & $(0.855)$ & 71 \\
Standard errors in parentheses & 71 & 0.888 \\
\hline \multirow{2}{*}{${ }^{* * *} \mathrm{p}<0.01,{ }^{* *} p<0.05,{ }^{*} p<0.10$} & 0.400 & \\
& & \\
& &
\end{tabular}

Second, the Protestan institutions have positive and significant impact on economic growth. The result are consistent with Wang and Lin. ${ }^{48}$ They argued that Cristian interpreted principle of economic as uphold freedom based 
on private property right, so it will encourage to making values, given that a improved life for the social order. Moreover, this result might as Weber claim on his book "The Protestant Ethic and the Spirit of Capilism" that the Protestant facilitated the rise of modern capitalism. However this result is different from the Barro and McCleary ${ }^{49}$ as well as McCleary and Barro. ${ }^{50}$ They found that Protestant share have negative impact on economic growth, and statisticaly significant.

Third, there is no strong evidence that Catholic institutions have significant impact on economic growth, although negative sign. It is consistent with Noland ${ }^{51}$ and Eum. ${ }^{52}$ However Barro and McCleary ${ }^{53}$ found that Catholic have negative impact and significant on economic growth. The difference result on Protestan and Catholic was confirmed by Putnam ${ }^{54}$, La Porta et al ${ }^{55}$, as well as Benjamin, Choi, and Fisher ${ }^{56}$ that Protestans more contribution on public goods than Catholics. In other case, Blum and Dudley found that in Europe the higher growth occurred in Protestant cities than Catholic cities. ${ }^{57}$

Fourth, Hindu has positif impact and significant on economic growth. This finding is differerence with Barro and McCleary ${ }^{58}$, Noland ${ }^{59}$, and Eum ${ }^{60}$. Deheija and Deheija argued that the living in Hindu aims to balancing between spiritual freedom (moksa) and material satisfaction (artha). ${ }^{61}$ In other words, the lessons of Hindu religion emphasize the balance between happiness of the world and the hereafter. Perhaps, this is what can encourage individuals to engage in more economic activities. Fifth, the result for Buddhist does not consistent, both of estimation. In the first model Buddhist institution have positive and significant effect on economic growth. However in the second model or full variable Budhist institution have no impact on economic growth, insignifican statisticaly. This finding is difference with Wang and Lin. ${ }^{62}$. They found that Buddhist institution have negative impact on economic growth in Chinese setting. Noland also found that in Malaysia, Budhhist proxy have negative impact on economic growth, yet insignificant statisticaly. However, in India setting Buddhist proxy have positif and significant effect on economic growth. ${ }^{63}$

\section{CONCLUSION}

This paper aims to investigate the impact of religion institutions on economic growth. The result shows that Protestan and Hindu institutions has positive and significant impact on economic growth. In contrast, Islam and Catholic institution do not have influence on economic growth significantly. 
The results of this study emphasize that the religious institutions in Protestant and Hindu are more effective to encourage social networks than Islam and Catholic institutions. An important point of this finding is that, in Indonesian context, religion also has influences on economic growth as in other countries. In other words, religion is one of the driving forces of economic activity, both at the individual and national level.

This study has two limitations, - in terms of - data availability and religious proxies. First, not all provinces in Indonesia have a complete data, making it difficult to estimate with more precision. Second, perhaps the religious institutions (number of places of worship) are not the right proxy to represent religion, therefore we need to find more appropriate variables Two limitations in this paper open up for further research, particularly in Indonesia. In addition, more research needs to be done related to the influence of religious institutions on the economy with a qualitative approach, in order to be able to capture more deeply the phenomenon. ***

\section{ENDNOTES}

1 Richard H. Franke, Geert Hofstede, and Michael H. Bond. "Cultural Roosts of Economic Performance: A Research Note”, Strategic Management Journal, Vol. 12, Special Issue: Global Strategy (Summer, 1991), pp. 165-173.

2 Burton A. Abrams and Kenneth A. Lewis, "Cultural and Institutional Determinants of Economic Growth/ : A Cross-Section Analysis”, Public Choice, 83, No. 3/4 (1995): 273-289.

3 John Adams, "Culture and Economic Development in South Asia", The American Journal of Economics and Sociology 52 (2001): 152-175

4 J. Haavard Maridal, "Cultural Impact on National Economic Growth”, Joumal of Socio-Economics 47 (2013): 136-146.

5 Panagiotis Petrakis and Pantelis Kostis, "Economic Growth and Cultural Change." Journal of Socio-Economics 47 (2013): 147-157.

6 J. Haavard. Maridal, "Cultural Impact on National Economic Growth.” Journal of Socio-Economics 47 (2013): 136-146.

7 Unbreen Qayyum, Sohail Anjum, and Samina Sabir, "Religion and Economic Development: New Insights”, Empirica. Springer US, 2019.

8 M. S. A. Rao, "Religion and Economic Development," Sociological Bulletin, No. 18, 1 (1969): 1-15.

9 Ulrich Blum and Leonard Dudley, "Religion and Economic Growth: Was Weber Right?”, Journal of Evolutionary Economics 11, No. 2 (2001): 207-230.

10 Robert J Barro, and Rachel M. McCleary, "Religion and Economic Growth across Countries.” American Sociological Review 68, No. 5 (2003): 760

11 Marcus Noland, "Religion and Economic Performance." World Development 
33, No. 8 (2005): 1215-32

12 Rachel M. McCleary and Robert J. Barro, "Religion and Economy." Journal of Economic Perspectives 20, No. 2 (2006): 49-72.

13 Wonsub Eum. "Religion and Economic Development -A Study on Religious Variables Influencing GDP Growth over Countries," Thesis in University of California, Berkeley. 2011.

14 Qunyong Wang and Xinyu Lin, "Does Religious Beliefs Affect Economic Growth? Evidence from Provincial-Level Panel Data in China", China Economic Review 31 (2014): 277-287.

15 Tiago Neves Sequeira, Ricardo Viegas, and Alexandra Ferreira-Lopes, "Income and Religion: A Heterogeneous Panel Data Analysis", Review of Social Economy 75, No. 2 (2017): 139-158.

16 Rachel M. McCleary and Robert J. Barro, "Religion and Economy", Journal of Economic Perspectives 20, No. 2 (2006): 49-72.

17 Ellen H. Palanca, "Religion and Economic Development", Philippine Studies 34, No. 2 (1986): 162-180.

18 Ewout Frankema and J. Thomas Lindblad, "Technological Development and Economic Growth in Indonesia and Thailand since 1950", Asean Economic Bulletin 23, No. 3 (2006): 303-324

19 Aris Ananta and Udi H Pungut, "Population Change and Economic Development in Indonesia”, ASEAN Economic Bulletin 9, No. 1 (1992): 55-65.

20 Wong Hock Tsen and Fumitaka Furuoka, "The Relationship between Population and Economic Growth in Asian Economies." ASEAN Economic Bulletin 22, No. 3 (2005): 314-331.

21 Mohammed B. Yusoff and Febrina, Ilza, "Trade Openness, Real Exchange Rate , Gross Domestic Investment and Growth in Indonesia”, Margin-The Journal of Applied Economic Research 81, No. 1 (2014): 1-13.

22 Ellen H. Palanca, "Religion and Economic Development" Philippine Studies 34, No. 2 (1986): 162-180.

23 Rachel M. McCleary and Robert J. Barro, "Religion and Economy", Journal of Economic Perspectives 20, No. 2 (2006): 49-72.

24 Qunyong Wang and Xinyu Lin, "Does Religious Beliefs Affect Economic Growth? Evidence from Provincial-Level Panel Data in China" China Economic Review 31 (2014): 277-287.

25 Robert J Barro, and Rachel M. McCleary, "Religion and Economic Growth across Countries", American Sociological Review 68, No. 5 (2003): 760

26 Marcus Noland, "Religion and Economic Performance" World Development 33, No. 8 (2005): 1215-32

27 Rachel M. McCleary and Robert J. Barro, "Religion and Economy", Journal of Economic Perspectives 20, No. 2 (2006): 49-72.

28 Qunyong Wang and Xinyu Lin, "Does Religious Beliefs Affect Economic Growth? Evidence from Provincial-Level Panel Data in China", China Economic Review 31 (2014): 277-287.

29 Tiago Neves Sequeira, Ricardo Viegas, and Alexandra Ferreira-Lopes, "Income 
and Religion: A Heterogeneous Panel Data Analysis", Review of Social Economy 75, No. 2 (2017): 139-158.

30 Isadora Kirchmaier, Jens Prüfer, and Stefan T. Trautmann, "Religion, Moral Attitudes and Economic Behavior", Journal of Economic Behavior and Organization 148 (2018): 282-300.

31 Liping Lu and Yiping Wu, "Does Religion Enhance Firm Performance? Evidence from Private Firms in China”, China Economic Review 62, No. May (2020)

32 Isadora Kirchmaier, Jens Prüfer, and Stefan T. Trautmann, "Religion, Moral Attitudes and Economic Behavior", Journal of Economic Behavior and Organization 148 (2018): 282-300.

33 Liping Lu and Yiping Wu, "Does Religion Enhance Firm Performance? Evidence from Private Firms in China", China Economic Review 62, No. May (2020)

34 Mehmet Karaçuka, "Religion and Economic Development in History: Institutions and the Role of Religious Networks", Journal of Economic Issues 52, no. 1 (2018): 57-79.

35 Robert D. Putnam, Making Democracy Work: Civic Tradition on Modern Italy, (Princeton University Press, 1993).

36 M.S. A. Rao, "Religion and Economic Development", Sociological Bulletin 18, No. 1 (1969): 1-15.

37 Qunyong Wang and Xinyu Lin, "Does Religious Beliefs Affect Economic Growth? Evidence from Provincial-Level Panel Data in China”, China Economic Review 31 (2014): 277-287.

38 Robert J Barro, and Rachel M. McCleary, "Religion and Economic Growth across Countries”, American Sociological Review 68, No. 5 (2003): 760

39 Jeffrey M. Wooldridge, Introductory Econometrics: A Modern Approach. 4e ed. (USA: South-WesternCengage Learning, 2009).

40 Frederic L. Pryor, "The Economic Impact of Islam on Developing Countries", World Development 35, No. 11 (2007): 1815-1835.

41 Marcus Noland, "Religion and Economic Performance", World Development 33, No. 8 (2005): 1215-1232.

42 Robert J Barro, and Rachel M. McCleary, "Religion and Economic Growth across Countries”, American Sociological Review 68, No. 5 (2003): 760.

43 Wonsub Eum, "Religion and Economic Development -A Study on Religious Variables Influencing GDP Growth over Countries," University of California, Berkeley. 2011.

44 Marcus Noland, "Religion and Economic Performance", World Development 33, No. 8 (2005): 1215-1232.

45 Qunyong Wang and Xinyu Lin, "Does Religious Beliefs Affect Economic Growth? Evidence from Provincial-Level Panel Data in China”, China Economic Review 31 (2014): 277-287.

46 Timur Kuran, Islam and Mammon, (Princeton University Press, 2004).

47 Frederic L. Pryor, "The Economic Impact of Islam on Developing Countries", World Development 35, No. 11 (2007): 1815-1835.

48 Qunyong Wang and Xinyu Lin, "Does Religious Beliefs Affect Economic Growth? 
Evidence from Provincial-Level Panel Data in China”, China Economic Review 31 (2014): 277-287.

49 Robert J Barro, and Rachel M. McCleary, "Religion and Economic Growth across Countries", American Sociological Review 68, No. 5 (2003): 760

50 Rachel M. McCleary and Robert J. Barro, "Religion and Economy", Journal of Economic Perspectives 20, No. 2 (2006): 49-72.

51 Marcus Noland, "Religion and Economic Performance", World Development 33, No. 8 (2005): 1215-1232

52 Wonsub Eum, "Religion and Economic Development -A Study on Religious Variables Influencing GDP Growth over Countries," University of California, Berkeley, 2011.

53 Robert J Barro, and Rachel M. McCleary, "Religion and Economic Growth across Countries”, American Sociological Review 68, No. 5 (2003): 760

54 Robert D. Putnam, Making Democracy Work: Civic Tradition on Modern Italy. (Princeton University Press, 1993).

55 Rafael La Porta, Florencio Lopes-de-Silanes, A. Shleifer, and R. W Vishny, "Trust in Large Organizations", The American Economic Review 87, No. 2 (1997).

56 Daniel J. Benjamin,, James J. Choi, and Geoffrey Fisher, "Religious Identity and Economic Behavior", Review of Economics and Statistics 98, No. 4 (2016): 617 637.

57 Ulrich Blum and Leonard Dudley, "Religion and Economic Growth: Was Weber Right?", Journal of Evolutionary Economics 11, No. 2 (2001): 207-230.

58 Robert J Barro, and Rachel M. McCleary, "Religion and Economic Growth across Countries”, American Sociological Review 68, No. 5 (2003): 760.

59 Marcus Noland, "Religion and Economic Performance", World Development 33, No. 8 (2005): 1215-32

60 Wonsub Eum. "Religion and Economic Development -A Study on Religious Variables Influencing GDP Growth over Countries," University of California, Berkeley. 2011.

61 Rajeev H. Deheija and Vivek H. Deheija, "Religion and Economic Activity in India: An Historical Perspective", The American Journal of Economics and Sociology, Vol. 52, No. 2 (April 1993) pp. 145-153.

62 Qunyong Wang and Xinyu Lin, "Does Religious Beliefs Affect Economic Growth? Evidence from Provincial-Level Panel Data in China”, China Economic Review 31 (2014): 277-287.

63 Marcus Noland, "Religion and Economic Performance," World Development 33, No. 8 (2005): 1215-1232

\section{REFERENCE}

Abrams. Lewis. "Cultural and Institutional Determinants of Economic Growth/ : A Cross-Section Analysis.” Public Choice 83, no. 3/4 (1995): 273-89.

Adams, John. "Culture and Economic Development in South Asia." The American Journal of Economics and Sociology 52 (2001): 152-75. http://www.jstor.org/ stable/1049019. 
Ananta, Aris, and Udi H Pungut. "Population Change and Economic Development in Indonesia.” ASEAN Economic Bulletin 9, no. 1 (1992): 55-65.

Barro, Robert J., and Rachel M. McCleary. "Religion and Economic Growth across Countries.” American Sociological Review 68, no. 5 (2003): 760. https://doi.org/ 10.2307/1519761.

Benjamin, Daniel J., James J. Choi, and Geoffrey Fisher. "Religious Identity and Economic Behavior." Review of Economics and Statistics 98, no. 4 (2016): 61737. https://doi.org/10.1162/REST_a_00586.

Blum, Ulrich, and Leonard Dudley. "Religion and Economic Growth: Was Weber Right?" Journal of Evolutionary Economics 11, no. 2 (2001): 207-30. https:// doi.org/10.1007/PL00003862.

Deheija, R. H., Deheija, V. H. "Religion and Economic Activity in India/ : An Historical Perspective.” The American Journal of Economics and Sociology 52, no. 2 (1993): 145-53.

Eum, Wonsub. "Religion and Economic Development -A Study on Religious Variables Influencing GDP Growth over Countries,” 2011. University of California, Berkeley.

Franke RH. Hofstede G. and Bond MH. "Cultural Roots of Economic Performance/ : A Research Note.” Strategic Management Journal 12, no. Special Issue: Global Strategy (1991): 165-73.

Frankema, Ewout, and J. Thomas Lindblad. "Technological Development and Economic Growth in Indonesia and Thailand since 1950.” Asean Economic Bulletin 23, no. 3 (2006): 303-24. https://doi.org/10.1355/ae23-3b.

Karaçuka, Mehmet. "Religion and Economic Development in History: Institutions and the Role of Religious Networks." Journal of Economic Issues 52, no. 1 (2018): 57-79. https://doi.org/10.1080/00213624.2018.1430941.

Kirchmaier, Isadora, Jens Prüfer, and Stefan T. Trautmann. "Religion, Moral Attitudes and Economic Behavior." Journal of Economic Behavior and Organization 148 (2018): 282-300. https://doi.org/10.1016/j.jebo.2018.02.022.

Kuran, Timur. Islam and Mammon. Princeton University Press, 2004. https://doi.org/ 10.1515/9781400837359.

Lu, Liping, and Yiping Wu. "Does Religion Enhance Firm Performance? Evidence from Private Firms in China.” China Economic Review 62, no. May (2020): 101480. https://doi.org/10.1016/j.chieco.2020.101480.

Maridal, J. Haavard. "Cultural Impact on National Economic Growth." Journal of Socio-Economics 47 (2013): 136-46. https://doi.org/10.1016/ j.socec.2012.08.002.

McCleary, Rachel M., and Robert J. Barro. "Religion and Economy." Journal of Economic Perspectives 20, no. 2 (2006): 49-72. https://doi.org/10.1257/ jep.20.2.49.

Mccleary, Rachel M, and Robert J Barro. "Religion and Economy." The Journal of Economic Perspectives 20, no. 2 (2006): 49-72.

Noland, Marcus. "Religion and Economic Performance." World Development 33, no. 8 (2005): 1215-32. https://doi.org/10.1016/j.worlddev.2005.03.006. 
Palanca, Ellen H. "Religion and Economic Development." Philippine Studies 34, no. 2 (1986): 162-80. http://www.jstor.org/stable/42633590.

Petrakis, Panagiotis, and Pantelis Kostis. "Economic Growth and Cultural Change." Journal of Socio-Economics 47 (2013): 147-57. https://doi.org/10.1016/ j.socec.2013.02.011.

Porta, R. La, F. Lopes-de-Silanes, A. Shleifer, and R. W Vishny. "Trust in Large Organizations.” The American Economic Review 87, no. 2 (1997). https:// www.jstor.org/stable/2950941.

Pryor, Frederic L. "The Economic Impact of Islam on Developing Countries." World Development 35, no. 11 (2007): 1815-35. https://doi.org/10.1016/ j.worlddev.2006.12.004.

Putnam, Robert D. Making Democracy Work: Civic Tradition on Modern Italy. Princeton University Press, 1993.

Qayyum, Unbreen, Sohail Anjum, and Samina Sabir. Religion and Economic Development: New Insights. Empirica. Springer US, 2019. https://doi.org/10.1007/ s10663-019-09456-3.

Rao, M. S. A. "Religion and Economic Development." Sociological Bulletin 18, no. 1 (1969): 1-15.

Sequeira, Tiago Neves, Ricardo Viegas, and Alexandra Ferreira-Lopes. "Income and Religion: A Heterogeneous Panel Data Analysis.” Review of Social Economy 75, no. 2 (2017): 139-58. https://doi.org/10.1080/00346764.2016.1195640.

Tsen, Wh, and Fumitaka Furuoka. "The Relationship between Population and Economic Growth in Asian Economies.” ASEAN Economic Bulletin 22, no. 3 (2005): 314-31. https://doi.org/10.1355/AE22-3E.

Wang, Qunyong, and Xinyu Lin. "Does Religious Beliefs Affect Economic Growth? Evidence from Provincial-Level Panel Data in China." China Economic Review 31 (2014): 277-87. https://doi.org/10.1016/j.chieco.2014.10.006.

Wooldridge, J. M. Introductory Econometrics: A Modern Approach. 4e ed. USA: SouthWestern Cengage Learning, 2009.

Yusoff, Mohammed B. Febrina, Ilza. "Trade Openness, Real Exchange Rate , Gross Domestic Investment and Growth in Indonesia." Margin-The Journal of Applied Economic Research 81, no. 1 (2014): 1-13. https://doi.org/10.1177/ 0973801013506398. 
